\title{
Duties and Authority of Fisheries in the State Fisheries Management Region of the Republic of Indonesia
}

\author{
AL Azhiim Tranggono ${ }^{1}$, Amalia Diamantina ${ }^{1}$, Sekar Anggun Gading P. ${ }^{1}$ \\ \{alztranggono@gmail.com*amalia_diamantina@live.undip.ac.id ${ }^{2}$, \\ sekar_anggun_gading@live.undip.ac.id ${ }^{3}$ \}
}

Fakultas Hukum, Universitas Diponegoro, Jl. Prof. H. Soedarto, S.H., Semarang, Indonesia 50275 1 , 2,3

\begin{abstract}
Indonesia is the largest archipelagic state in the world, with marine waters covering 5.8 million $\mathrm{km}^{2}$. This potential places Indonesia as a rich country based on the high potential of fishing, but at the same, it can be a great target for illegal fishing This research addresses the phenomenon of the fisheries controller's duties and authorities in fishery management zones of the State of the Republic of Indonesia 716 in North Sulawesi. Based on the results of the research, it is found out that the fisheries supervisor already carried out supervisory tasks, including the validation checks of SIPI and SIKPI, Operational Feasibility Letter and Sailing Approval Letter, validation checks of fisheries research and development, checks of vessels, fishing equipment, and/or fishing aids, checking the suitability of fish caught with fishing gear, and logbook checks. However, there are still many problems with the control of the fishery management zones of the State of the Republic of Indonesia 716 in North Sulawesi such as the lack of optimization of Rumpon, data, and human resources of controller. More efforts and improvements are needed.
\end{abstract}

Keywords: Duties and Authorities, Fisheries Controller, Fishery Management Zones of the State of the Republic of Indonesia 716.

\section{Introduction}

Indonesia is the largest archipelago country in the world which has a wider sea area compared to the mainland with a coastline of $81,000 \mathrm{~km}$ and a sea area of about 3.1 million $\mathrm{km} 2$ or $62 \%$ of its territorial area consisting of 2.8 million $\mathrm{km} 2$ of inland waters and 0,3 million $\mathrm{km} 2$ of the territorial sea. It does not include 2.7 million $\mathrm{km} 2$ of the Exclusive Economic Zone.

This fact shows that the prospect of fisheries and marine development in Indonesia is great and it can be used for the future of the nation and for the use in national development. Besides having economic value, marine resources also have ecological value. In addition, Indonesia's geographical condition lies in strategic geopolitics between the Pacific Ocean and the Indian Ocean which is the most dynamic region in the world of political, defense and security disputes.[1] 
Fish resources that live in the territorial waters of Indonesia are considered to have the highest level of biodiversity (bio-diversity). These resources cover at least $37 \%$ of the world's fish species. In Indonesia's marine waters, there are several types of fish with high economic value, including tuna, skipjack, shrimp, tuna, mackerel, snapper, squid, reef fish (grouper, baronang, barong shrimp/lobster), ornamental fish and drought including seaweed. However, there are various gaps that still color fisheries development in Indonesia, both nationally and locally administratively are managed by. Various infrastructures built by the government, such as the construction of fishing ports and fish landing places which are scattered in various regions have not produced satisfactory results as expected. Various regulatory models and policies have not been able to touch well on the underlying problems that exist.[2]

The problem of illegal fishing (fishing theft) and weak law enforcement have eliminated the potential for Indonesian fishery exports of 4 billion US dollars. Beside affecting the national economy, illegal fishing also affects traditional fishermen since they use trawling fishing gear that causes damage to the marine environment. Illegal fishing can also weaken the management of fisheries resources in Indonesian waters and cause fisheries resources in several Fisheries Management Areas (WPP) of Indonesia to experience overfishing.[3] Overfishing is a term or status given to an area of water whose fish resources have experienced overfishing. Over-fishing is meant if the rate of fishing carried out has exceeded the ability of these fish resources to recover.[4]

Illegal fishing is very detrimental to the country and traditional fishermen. In addition, Indonesian consumers are disadvantaged because they cannot enjoy sea products in their own country. At a macro level, the stolen Indonesian fish are then processed with qualified equipment, thus increasing the price of sale abroad.[5]

Illegal Fishing also has a very detrimental impact on the country's finances and even harmed the economy. World Food and Agriculture Organization (FAO) stated that Indonesia's losses due to IUU Fishing are estimated at Rp. 30 trillion per year. FAO also stated that currently, the catch of fish resources in the world which is still possible to increase its catch is only 20 percent, while 55 percent is already in full utilization and the remaining 25 percent is threatened with its sustainability.[6] Other economic losses are the loss of economic value of stolen fish, Fishery Product Levies (PHP) will be lost, and fuel subsidies enjoyed by unauthorized fishing vessels.

Illegal Fishing problems occur because of two things, overlapping laws and regulations which lead to unclear Indonesian state institutions taking care of Illegal Fishing issues. It will create conflicts of interest between state institutions in managing their respective working areas, such obscurity creating a legal loophole for the perpetrators of the Illegal Fishing crime.[7]

There are also things that needs to be taken into consideration so that the sustainability of Indonesian fisheries resources can still be guaranteed well. The thing that must be done is the rearrangement of the national fisheries system by means of rational management of fish resources (restrictions on catches, and catches). Management of fish resources in a gradual and controlled manner, followed by careful monitoring for the sustainability of fish resources sustainably. There will be careful monitoring, control, and monitoring of fleets, fishing gear and fishermen to reduce the risk of IUU Fishing activities that harm the country.

Based on data from the Ministry of Maritime Affairs and Fisheries (KKP) on the results of the operation of the fishery watchdog the Supervision of Marine Resources and Fisheries (PSDKP) states that during the first half of 2017 there were 95 illegal vessels conducting illegal fishing in Indonesian waters. [8] Earlier in 2016, Minister Susi Pudjiastuti said there were 8 illegal vessels that were captured by the Maritime and Fisheries Ministry's (KKP) 
fisheries surveillance vessel. The eight vessels were suspected of carrying out illegal fishing activities. The Minister of Maritime Affairs and Fisheries, Susi Pudjiastuti, said that the arrests were carried out by KP Leopard Shark 001 and Tiger Shark 0606 on September 22-23, 2016, in the Fisheries Management Area of the Republic of Indonesia (WPP-RI) 716, namely in the waters of the Sulawesi Sea.[9]

Illegal fishing cases also occurred in April 2018, the Ministry of Maritime Affairs and Fisheries (KKP) again arrested Foreign Fishing Vessels that were fishing illegally in Indonesian waters. Sharks 011 fishing vessel (KP) Shark caught two Philippine-flagged foreign vessels in the Indonesian Fisheries Management Area (WPP-RI). The two vessels arrested were FB LB John V (16.47 GT, three crew) and FB LB Luke V (15.60 GT, two crew), all Filipino citizens. During inspection by the Leopard Shark KP 001, the two vessels did not have a single permit document to conduct fishing activities from the Government of the Republic of Indonesia, so both ships were escorted and handed over to the Bitung PSDKP base.[10]

North Sulawesi also has problems besides illegal fishing including the potential of fisheries and marine resources that have not been managed properly, such as pollution of the sea to destructive fishing. In addition, some of Indonesia's large potential coastal and marine resources apparently have not contributed significantly to national economic development. Utilization has not been optimal yet, and it creates the degradation of natural resources in some coastal waters due to utilization that does not consider the carrying capacity of the environment. [11]

The high level of Illegal Fishing occurring in Indonesian waters especially in the WPP 716 fisheries management area shows a lack of supervision in the area. Utilization of marine and fisheries resources needs to be accompanied by optimal supervision in order to ensure the sustainability and sustainability of marine and fisheries resources. Oversight of marine and fisheries resources is carried out to protect marine and fisheries resources from destruction and illegal activities.[12]

\section{Method}

This study is qualitative because it focuses more on the depth of the data than the amount of data obtained. Viewed from a scientific perspective, this research is a legal research, with the method of juridical-normative approach. This kind of research places the rule of law as the major premise or determinant factor of a legal research.[13]

The juridical-normative approach method is a research method that emphasizes understanding in obtaining answers by basing on legal principles and principles that are reviewed from the regulations and trying to synchronize the applicable legal provisions with the applicable rules of law in the protection of the law against legal norms or regulations.[12]

In practice to obtain a comprehensive understanding in analyzing the problems of legal research, according to Soerjono Sukanto, normative legal research methods or legal literary research methods are methods used in the legal research conducted by examining existing library materials.[13]

The research specifications used in writing this law are analytical descriptive. A descriptive analytical method is a method that serves to describe the object within a particular area by linking to existing legal theories and in accordance with the laws and regulations under the study.[14] 
Based on the approach method used, namely Juridical-Normative, the main data used is secondary data. Secondary data in this study are divided into:

1. Primary legal materials including the provisions of the national laws of Indonesia which are related to the writing of this law.

a. The 1945 Constitution of the Republic of Indonesia; [15]

b. Act Number 31 of 2004 as amended by Act Number 45 of 2009 concerning Fisheries; [16]

c. Law Number 23 of 2014 concerning Regional Government; [17]

d. Regulation of the Minister of Maritime Affairs and Fisheries of the Republic of Indonesia Number PER.01/MEN/2009 concerning the territory of the Republic of Indonesia Fisheries Management. [18]

2. Secondary legal material to explain the primary legal material in the form of scientific work of scholars such as: [19]

a. Books, both printed and electronic versions

b. Scientific journals

c. Website pages that are closely related to the subject matter in this study.

In the data collection method based on the data sources obtained in this study, the data collected by means of library research (library research), which consists of primary legal materials, and secondary legal materials as well as previous research related to the object of this research study that can be in the form of interviews and statutory regulations, literature and scientific papers.

Data analysis is very important in a study in order to provide answers to the problems studied. Before data analysis is performed, data collection is first prepared. The method used in analyzing and processing the collected data is qualitative analysis. [19]

Qualitative Analysis is research that aims to understand the phenomena about what is experienced by research subjects, such as behavior, perception, and action. [20] Qualitative analysis mainly uses library materials as a source of research data.

\section{Results and Discussion}

\subsection{The territory of the Republic of Indonesia fisheries Management}

Fisheries Management Area according to the Regulation of the Minister of Maritime Affairs and Fisheries of the Republic of Indonesia Number 18/PERMEN-KP/2014 is a fisheries management area for fishing, fish cultivation, conservation, research, and fisheries development which includes inland waters, archipelagic waters, territorial sea, additional zones, and Indonesia's exclusive economic zone. The Fisheries Management Area is divided into 11 regions, namely:

1. WPP NRI 571 covers the waters of the Malacca Strait and the Andaman Sea;

2. WPP NRI 572 covers the waters of the Indian Ocean to the west of Sumatra and the Sunda Strait;

3. WPP NRI 573 covers the waters of the Indian Ocean south of Java to the south of Nusa Tenggara, the Sawu Sea and the West Timor Sea;

4. WPP NRI 711 covers the waters of the Karimata Strait, the Natuna Sea and the South China Sea; 
5. WPP NRI 712 covers the waters of the Java Sea;

6. WPP NRI 713 covers the waters of the Makassar Strait, Bone Bay, Flores Sea, and Bali Sea;

7. WPP NRI 714 covers the waters of the Tolo Bay and the Banda Sea;

8. WPP NRI 715 covers the waters of Tomini Bay, Maluku Sea, Halmahera Sea, Seram Sea and Berau Bay;

9. WPP NRI 716 covers the waters of the Sulawesi Sea and the northern part of Halmahera Island;

10. WPP NRI 717 includes waters of the Cendrawasih Bay and Pacific Ocean;

11. WPP NRI 718 covers the waters of the Aru Sea, Arafuru Sea and East Timor Sea.

\subsection{Republic of Indonesia Fisheries Management Region 716 in North Sulawesi}

The Fisheries Management Area 716 covers the waters of the Sulawesi Sea and Halmahera Sea. Administratively, WPP 716 in the north is bordered by the outer boundary of the Indonesia - Philippines ZEE; to the east bordering the outer boundaries of the Indonesia Palau ZEE; in the south bordering North Halmahera Regency, North Maluku Province, Gorontalo Province, North Sulawesi Province, Tolitoli Regency, Donggala Regency, Central Sulawesi Province; and in the west bordering the Indonesia - Malaysia land border.

In general, WPP 716 in the north bordering the Indonesia - Malaysia land border on Borneo Island which is drawn along the Indonesia - Malaysia territorial sea boundary on Sebatik Island, then following the outer boundary of the Indonesia - Malaysia ZEE, followed by the outer border of the Indonesia - Philippines ZEE, then following the outer boundary of EEZ Indonesia - Palau, then drawn a line to the Sele promontory on Morotai Island, North Halmahera Regency, North Maluku Province; in the east bordering the outer border of ZEE Indonesia - Palau in the west; in the south bordering the North Lengen coastline over Sulawesi Island in North Sulawesi Province, Gorontalo Province and Central Sulawesi Province ending the border between Donggala Regency and Tolitoli Regency in Central Sulawesi Province, continuing towards the border of Berau Regency and East Kutai Regency in East Kalimantan Province ; and in the west bordering the border of Berau Regency and East Kutai Regency in East Kalimantan Province then along the East coast of Kalimantan Island and ending at the land border between Indonesia - Malaysia in Nunukan Regency. [21]

The great potential of fisheries and direct borders with other countries makes the 716 State Fisheries Management Area of the Republic of Indonesia vulnerable to illegal fishing. North Sulawesi's waters are one of the red zones of illegal fishing. [22] The perpetrators of fish theft from several countries often take wealth of fisheries resources, especially tuna and skipjack commodities. According to the Minister of Maritime Affairs and Fisheries, Susi Pudjiastuti, Bitung in North Sulawesi is the main satellite city for the center of illegal fishing activities carried out by other countries. During that time, other countries such as the Philippines benefited from that illegal activity and even received significant foreign exchange earnings. Besides the Philippines, other countries such as Thailand, Vietnam and Malaysia did the same things. [23]

In addition, WPP 716 is also filled with fishing activities in destructive ways. Therefore, supervision is needed in the field of marine and fisheries resources and the availability of supervisory facilities and infrastructure. 


\subsection{Implementation of Duties and Authority of Fisheries Supervisors in Fisheries Management Areas 716 Based on Law Number 45 of 2009 concerning Amendment to Law Number 31 of 2004 concerning Fisheries}

Indonesian waters which are within the sovereignty of the Unitary Republic of Indonesia and Indonesia's Exclusive Economic Zone are the place for high seas that contains potential fish resources., By taking into account, the existing carrying capacity and its sustainability to be utilized as much as possible for the welfare and prosperity of the Indonesian people.

Optimal utilization is directed at the utilization of fish resources by taking into account the existing carrying capacity and sustainability to improve the welfare of the people, to improve the living standards of small fishermen and small-fish growers, to increase revenue from the country's foreign exchange, to provide expansion and employment opportunities, and to increase productivity, value added and competitiveness of fishery products and guarantee the preservation of fish resources, fish cultivation land and spatial planning. This means that the utilization of fishery resources must be balanced with the carrying capacity, so that it will last long. One of the activity to achieve all of those benefits is by controlling the fisheries business through fisheries supervision.

The potential of marine and fisheries resources will be focused on the potential of living natural resources in North Sulawesi Province. The fisheries potential of North Sulawesi Province, namely: [21]
a. Potential of Freshwater Fisheries
b. Potential of Sea Water Fisheries
c. Potential of Sea Cultivation

The fishery supervisory duties are further regulated in the Regulation of the Minister of Maritime Affairs and Fisheries of the Republic of Indonesia Number 17/PERMEN-KP/2014 Regarding the Implementation of the Fishery Supervisory Duties, regulating:

\subsubsection{Checking the Completeness and Legitimacy of SIPI and/or SIKPI, Operating Declaration, and Sailing Approval Letter}

Fishery Supervisors in carrying out a fishery supervision activity are required to check the completeness of SIPI and/or SIKPI, Operational Worthy Letter, and Sailing Approval Letter. Fishing Permit (SIPI) is a written permit that must be owned by every fishing vessel to do fishing which is an inseparable part of SIUP. Fisheries Business License (SIUP) is a written permit that must be owned by a fishery company to conduct a fishery business using the production facilities listed in the permit. Fish Transport Boat Permit, hereinafter referred to as SIKPI, is a written permit that must be owned by every fishing vessel to transport fish.

\subsubsection{Checking the Completeness and Legitimacy of SIPI and/or SIKPI, Operating Declaration, and Sailing Approval Letter}

Permit for fisheries research and development is given to fisheries research vessels. During this time in WPP 716 there are a number of research vessels that are used to conduct research. The fishery supervisor in this case is also obliged to check the completeness and validity of the research and development permit for the ship's fisheries. Some research vessels conducting fisheries development in WPP 716 include:

1. Research ship of the Indonesian Institute of Sciences, KM Baruna Jaya VIII in Tahuna, Sangihe Islands, North Sulawesi in the context of developing science and fisheries in October 2018. [24] 
2. Research ship from China, R.V. KEXUE at the Port of Bitung in order to add insight into maritime science in January 2018. [25]

3. Research ship from the National Oceanic and Administration (NOAA) of the United States Department of Commerce, the Okeanos Explorer in North Sulawesi Waters to keep researching about the national environment, maritime affairs, weather and marine security programs in collaboration with the Central Agency for Assessment Technology (BBPT) Indonesia in June 2010. [26]

\subsubsection{Checking the Completeness and Legitimacy of SIPI and/or SIKPI, Operating Declaration, and Sailing Approval Letter}

The Fishing Vessel Monitoring System (SPKP) has the understanding as one of the fishing vessel monitoring systems using predetermined equipment to determine the movement and activities of fishing vessels. This is regulated in the Regulation of the Minister of Maritime Affairs and Fisheries of the Republic of Indonesia Number 42/PERMEN-KP/2015 Regarding Fisheries Vessel Monitoring System. SPKP is the implementation of fisheries supervisory duties in the form of monitoring the movement of ships. SPKP also known as Vessel Monitoring System (VMS) is a satellite-based fishing vessel monitoring system to determine the movement and activity of fishing vessels.

Since 2003, SPKP has been implemented by installing transmitters on fishing vessels of more than 30 GT sizes. [27]

\subsubsection{Checking Fishing Vessels, Fishing Tools, and/or Fishing Aids}

Applying fishing vessel policy to use fishing gear in accordance with the provisions in Article 6 of the Regulation of the Minister of Maritime Affairs and Fisheries of the Republic of Indonesia Number 71/PERMEN-KP/2016 Regarding Fishing Line and Placement of Fishing Equipment in the Fisheries Management Area of the Republic of Indonesia.

With eight groups of types of fishing gear. Based on the table above, it can be seen that there are two groups of dominant fishing gear types, namely fishing rods and gill nets, as many as 32,377 units. Therefore, the groups of fish species to be managed are the dominant fish species caught with two groups of fishing gear types.

When conducting a surveillance patrol by inspecting fishing vessels, fishing gear, and/or fishing aids, the fishery inspector in WPP 716 found a foreign fishing vessel with a Philippine flag, namely FB LB John V (16.47 GT with three ABK Filipino citizens) and FB LB Luke V (15.06 GT with two crew of Filipino citizens) in April 2018 who carried out illegal fishing using a type of FAD fishing gear without having a FAD Installation License (SIPR) as regulated in in the Regulation of the Minister of Maritime Affairs and Fisheries of the Republic of Indonesia Number 26/PERMEN-KP/2014 concerning FADs. [28]

\subsubsection{Checking the Compliance of the Composition of Fishing Vessels by Examining the Existence of Monitors on Fishing Vessels or Fishing Vessels for Specific Fishing Measures and Equipment}

The fishery supervisor in WPP 716 checks the suitability of the number of crew on board in accordance with what is stated in the Fishing License (SIPI) by checking the presence of the monitor on a fishing vessel or a fish carrier. Monitoring of fishing vessels and fishing vessels are only done by the experts, which is regulated in the Regulation of the Minister of Maritime Affairs and Fisheries of the Republic of Indonesia Number 1/PERMEN-KP/2013 Regarding Vessel Monitoring Fish Catchers and Fish Transport Vessels. 
Monitoring of fishing and transportation of fish assigned by the Director General on fishing vessels that use fishing gear fishing groups, ring nets, lift nets, gill nets, trawl trawls, and trawlers for vessels operating in WPP 716.

\subsubsection{Checking Compliance with Fish Handling on Fishing Vessels}

Examination of the suitability of fish handling on board by the fishery supervisor in WPP 716 is regulated in the Decree of the Minister of Maritime Affairs and Fisheries of the Republic of Indonesia Number 52A/KEPMEN-KP/2013 Regarding the Requirements of Quality Assurance and Safety of Fishery Products in Production, Processing and Distribution Processes. The fishing vessels and fish carriers used must meet the sanitary and hygiene requirements of the ship.

Ships must be equipped with equipment to maintain the freshness of fish for more than 24 hours and freezers (freezer), and equipped with hold equipment, tanks, or containers to store fish and keep the cooling temperature at the melting point of ice. Based on the inspection carried out in WPP 716, all ships are equipped with equipment to maintain the freshness of fish on board. Cooling must be undertaken in proper so that the fish are not infected and does not cause physical damage to fish.

The fish must be stored separately and must, stored in a fiber/styrofoam box or insulated hatch with added ice with a ratio of the amount of ice and fish used is 1: 1 where the entire surface of the fish must be covered with ice. If the fish are arranged stacked, then the composition is ice-fish-ice-fish-ice and the ice used is ice that has been crushed (bulk ice) because it will contact with the body of the fish evenly.

\subsubsection{Checking the Suitability of Fish Catches with Fishing Equipment}

Examination of the suitability of catching fish with fishing gear in WPP 716 is carried out by fisheries supervisors in accordance with the Decree of the Minister of Maritime Affairs and Fisheries of the Republic of Indonesia Number 52A/KEPMEN-KP/2013 Regarding the Requirements of Quality Assurance and Safety of Fishery Products in Production, Processing and Distribution Processes.

The suitability of the catching fish with the fishing gear must be harmonized to ensure the quality of the catched fish follow requirements by not using fishing technology that can physically damage the fish, by not using fishing gear that can accelerate the decline in fish quality and cause the fish to be contaminated eg catch using poison, by not catching fish in the contaminated area, and not to catch fish in the spawning area and season thus reducing fish quality.

\subsubsection{Checking the Application of Fishing Book Log}

The fishery supervisor in WPP 716 checks the implementation of the fishing log book. This is regulated in the Regulation of the Minister of Maritime Affairs and Fisheries of the Republic of Indonesia Number 48/PERMEN-KP/2014 Regarding the Fishing Book Log. Fishing Log Book is a daily report written by the skipper regarding fishing activities and daily fishing vessel operations which contains information about fishing vessel data, fishing gear data, fishing operation data, and catching fish data.

However, in fact, the use of Log Books manually is not that easy. The paper easily gets wet, and therefore it is hard to read. In addition, the application of the Log Book still does not in advance benefit to fishermen, so they do not feel they have an obligation to fill in the results of their capture in the established Log Book. [29] 
To overcome those, an electronic based fishing book has been developed or known as an e-log book. So that more accurate fisheries data and information can be obtained to support optimal and sustainable fish resource management policies and guaranteed sustainability of fish resources.

E-Log Book has several advantages, which is practical, more efficient, and paperless. To report the submission, it does need to go to the office, and instead to just send the ready data when online.[29]

\subsection{Obstacles of the North Sulawesi Provincial Government in Supervision and Protection Efforts of the Republic of Indonesia Fisheries Management Areas 716}

The 716 Fisheries Management Area is one of the strategic fishing areas in Indonesia. Given the high potential of fish resources in North Sulawesi, Indonesia must make efforts to supervise and protect the marine potential of North Sulawesi. However, fisheries supervisors in the 716 Fisheries Management Area, especially in the North Sulawesi sea, have obstacles in carrying out fisheries supervision activities. There are some alleged violations of the election administration, and can review reports and findings which are then recommended to the authorities, resolve election disputes, appoint and dismiss members of the Provincial Bawaslu.

\subsubsection{Not yet optimal management of FADs in WPP 716 so that it has the potential to Catch Unwanted Bycatch}

FADs, according to the Regulation of the Minister of Maritime Affairs and Fisheries of the Republic of Indonesia Number 26/PERMEN-KP/2014, are fish collecting aids that use various forms and types of binders/contractors of solid objects, functions to lure fish to gather, which are used to increase efficiency and the effectiveness of fishing operations. FADs in foreign terms are called fish aggregating devices (FAD) or payaos (for Filipino sailors) is a type of buoy that is installed at sea to attract fish gathered nearby before being caught by fishermen.

The use of FADs associated with fishing gear tends not to be selective, such as purse seine nets has increased the risk of catching baby tuna and non-target species such as dolphins, turtles, sharks, or other biota. This could potentially lead to the capture of unwanted bycatch.

Every citizen who wants to install FADs in NRI WPP is required to have a FAD Installation License (SIPR), including WPP 716. However, it was found by fisheries supervisors that the use of FADs that do not have SIPR such as Philippine FB flagged vessels John V (16, 47 GT with 3 ABK Filipino citizens) in April 2018 who used FAD without having a FAD Installation License (SIPR). [28]

Optimum management of FADs can be done by socializing legislation related to FADs as stipulated in the Regulation of the Minister of Maritime Affairs of the Republic of Indonesia Number 26/PERMEN-KP/2014 About FADs, conducting data collection and evaluating the status of FADs distribution, giving FAT permits (new and extension) in accordance with the results of evaluations and provisions of laws and regulations, as well as supervising and enforcing business actors who do not implement the provisions of the laws and regulations related to FADs.

\subsubsection{Limited Data to Support Fisheries Oversight in WPP 716}

The availability of fisheries data that can meet the interests of fisheries resource management is an important thing that can facilitate fisheries supervision in WPP 716. This 
can be done by improving the facilities and infrastructure for collecting fisheries statistics and fishing log books, implementing technical guidance for collection and processing fisheries statistical data, carrying out technical guidance on filling the fishing Log Book, increasing the number of enumerator data collection officers and fishing Log Book officers.

In November 2018, the Ministry of Maritime Affairs and Fisheries has begun implementing an electronic Log Book (e-Log Book) system to record fish catching. However, this application has only been implemented in several regions. Socialization is needed to regions in Indonesia related to the e-Log Book system. This is expected to facilitate the fisheries product data collection system to support supervision, especially in WPP 716.

Improvements continue to be made in WPP 716 in collecting data on catches. Data collection using the e-Log Book continues to be carried out by fisheries supervisors in WPP 716 in the hope that it will facilitate fishermen in providing complete and accurate data to fisheries supervisors in WPP 716.

The improvement in the data collection of fish catching is also done by educating the fishermen conducted by the fishery supervisor by telling them how to use and activate the eLog Book.

\subsubsection{Lack of Human Resources (HR) Fisheries Supervisors}

The condition of fisheries supervisors' human resources that are not in accordance with the conditions of WPP 716 has caused fisheries supervision activities to not run optimally. The factor of human resources supervision is quite important because the condition of the region in WPP 716 is that there are a lot of islands so that with adequate elements of human resources can conduct surveillance activities properly. In WPP 716, in the office of the Tahuna Marine and Fisheries Resources Supervision Station, North Sulawesi only has 12 personnel and consists of 6 Fisheries Supervisors. This number is not proportional to the number of fishing vessels being monitored which has approximately 82 recorded fishing vessels in the Tahuna Marine and Fisheries Resources Monitoring Station and also in the Sangihe Regency District in WPP 716 there are many fishery centers so that fishing activities are not maximized.[30] It is necessary to increase the number of personnel so that fishery supervision activities in WPP 716 can be carried out properly.

\section{Conclusion}

Based on the description that has been explained in the discussion., it can be concluded as follows:

1. Implementation of the duties and authority of fisheries supervisors in the Republic of Indonesia 716 Fisheries Management Area (WPP NRI 716) is carried out by fisheries supervisors in accordance with Law Number 45 of 2009 amended from Law Number 31 of 2004 concerning Fisheries conducted with patrol supervision and monitoring of fishing vessel movements in the form of:

a. checking the completeness and validity of SIPI and/or SIKPI, Operating Declaration, and Sailing Approval Letter;

b. checking the completeness and validity of a fisheries research and development permit;

c. checking the equipment and activeness of the fishing vessel monitoring system;

d. inspecting fishing vessels, fishing equipment, and/or fishing aids; 
e. checking the suitability of the composition of the fishing vessel crew by checking further on the presence of the monitor on a fishing vessel or fish carrier vessel for a certain size and fishing equipment;

f. checking the suitability of fish handling on a fishing boat;

g. checking the suitability of the fish caught with a fishing gear;

h. checking the application of fishing log books.

2. The obstacles faced by fisheries supervisors in North Sulawesi in conducting fisheries supervision are as follows:

a. The management of FADs in WPP 716 is not yet optimal so that it still allows to catch unwanted bycatch (Unwanted Bycatch) such as baby tuna, dolphins, turtles, sharks, or other biota.

b. The data is limited to support fisheries supervision in WPP 716 .

c. The lack of human resources (HR) of fisheries supervisors that prevents fishery supervision activities to run optimally. 


\section{References}

[1] Humas Sekretariat Kabinet Republik Indonesia, "Potensi Besar Perikanan Tangkap Indonesia," 4 Mar 2016. [Online]. Available: http://setkab.go.id/potensi-besarperikanan-tangkap-indonesia/. [Accessed: 07-Sep-2018].

[2] S. V. Muhamad, "Illegal Fishing Di Perairan Indonesia: Permasalahan Dan Upaya Penanganannya Secara Bilateral Di Kawasan," J. Polit. Din. Masal. Polit. Dalam Negeri dan Hub. Int., vol. 3, no. 1, pp. 59-85, 2016.

[3] D. Sunyowati, Port State Measures dalam Upaya Pencegahan terhadap IUU Fishing di Indonesia, Peran Hukum dalam Pembangunan di Indonesia. Bandung: Remaja Rosdarkarya, 2013.

[4] S. A. Murawski, "Definitions of overfishing from an ecosystem perspective," ICES J. Mar. Sci., vol. 57, no. 3, pp. 649-658, 2000.

[5] D. Tribawono, Hukum Perikanan Indonesia. Jakarta: Citra Aditya Bakri, 2011.

[6] Politik Indonesia, "Indonesia Kerepotan Berantas Illegal Fishing (interview with Ida Kusuma Wardhaningsih)," 20 Apr 2014. [Online]. Available: http://polindo.id/index.php?k=wawancara\&i=55554. [Accessed: 08-Sep-2018].

[7] A. Solihin, Politik hukum kelautan dan perikanan: isu, permasalahan, dan telaah kritis kebijakan. Bandung: Nuansa Aulia, 2010.

[8] Tempo, "Sepanjang 2017, 95 Kapal Illegal Ditangkap Menteri Susi," 27 Jul 2017. [Online]. Available: https://bisnis.tempo.co/read/894780/sepanjang-2017-95-kapalillegal-ditangkap-menteri-susi/full\&view=ok. [Accessed: 08-Sep-2018].

[9] E. Suryowati, “Kapal Pengawas KKP Tangkap Delapan Kapal Perikanan Ilegal,” 27 Sept 2016. [Online]. Available: https://money.kompas.com/read/2016/09/27/190000826/kapal.pengawas.kkp.tangkap. delapan.kapal.perikanan.ilegal. [Accessed: 10-Sep-2018].

[10] Koran Sindo, "Kementerian Kelautan dan Perikanan Tangkap 2 Kapal Ikan Filipina," 12 Apr 2018. [Online]. Available: https://daerah.sindonews.com/berita/1297383/174/kementerian-kelautan-danperikanan-tangkap-2-kapal-ikan-filipina. [Accessed: 07-Sep-2018].

[11] V. Sarempaa, E. S., Mantjoro, E., and Lumenta, "Kondisi Perusahaan Perikanan di Kota Bitung Pasca Moratorium 2014," Akulturasi-Jurnal Ilm. Agrobisnis Perikan., vol. 5, no. 9, pp. 135-147, 2017.

[12] Direktorat Jenderal Pengawasan Sumber Daya Kelautan Dan Perikanan, Data Dan Informasi Pengawasan Sumber Daya Kelautan Dan Perikanan. Jakarta: PSDKP Press, 2013.

[13] S. Soekanto, S., and Mamudji, Penelitian Hukum Normatif: Suatu Tinjauan Singkat, 11th print. Jakarta: PT. RajaGrafindo Persada, 2009.

[14] R. H. Soemitro, Metodologi Penelitian Hukum dan Jurimateri. Jakarta: Ghalia Indonesia, 1990.

[15] The 1945 Constitution of the Republic of Indonesia. . 
[16] Act Number 31 of 2004 as amended by Act Number 45 of 2009 concerning Fisheries. .

[17] Law Number 23 of 2014 concerning Regional Government. .

[18] Regulation of the Minister of Maritime Affairs and Fisheries of the Republic of Indonesia Number PER.01/MEN/2009 concerning the territory of the Republic of Indonesia Fisheries Management. .

[19] J. Ibrahim, Teori \& Metodologi Penelitian Hukum Normatifitle. Malang: Bayumedia Publishing, 2011.

[20] L. J. Moleong, Metode penelitian kualitatif, revised edition. Bandung: Remaja Rosdakarya, 2006.

[21] D. M. R. Siombo, No Hukum Perikanan Nasional dan Internasional. Jakarta: Gramedia Pustaka Utama, 2013.

[22] B. Gokkon, "No TitleIndonesia's crackdown on illegal fishing is paying off, study finds," 23 April 2018. [Online]. Available: https://news.mongabay.com/2018/04/indonesias-crackdown-on-illegal-fishing-ispaying-off-study-finds/. [Accessed: 16-Jan-2019].

[23] M. Ambari, "No TitlePerlu Cara Tak Biasa untuk Berantas IUU Fishing, Bagaimana?," $26 \quad$ Aug $2018 . \quad$ [Online]. Available: https://www.mongabay.co.id/2018/08/26/perlu-cara-tak-biasa-untuk-berantas-iuufishing-bagaimana/. [Accessed: 16-Jan-2019].

[24] J. Mendalora, "Kapal riset LIPI kunjungi Kepulauan Sangihe," 14 Oct 2018. [Online]. Available: https://www.antaranews.com/berita/758283/kapal-riset-lipi-kunjungikepulauan-sangihe. [Accessed: 16-Jan-2019].

[25] Klik Sulut, "Awal Tahun 2018, Taruna BDP MInsel Berkunjung Ke Kapal Riset China," 19 Jan 2018. [Online]. Available: http://kliksulut.com/246-awal-tahun-2018taruna-bdp-minsel-berkunjung-ke-kapal-riset-china-rv-kexue.html. [Accessed: 16-Jan2019].

[26] Tribun News, "Peneliti AS Survei Potensi Perairan Sulut," 5 Jun 2010. [Online]. Available: $\quad$ https://www.tribunnews.com/regional/2010/06/05/peneliti-as-surveipotensi-perairan-sulut. [Accessed: 16-Jan-2019].

[27] Kementerian Kelautan dan Perikanan Republik Indonesia, "FAQ Sistem Pemantauan Kapal Perikanan VMS (Vessel Monitoring System)," 1 Mar 2018. [Online]. Available: https://kkp.go.id/artikel/2636-faq-sistem-pemantauan-kapal-perikananvms-vessel-monitoring-system. [Accessed: 14-Jan-2019].

[28] I. Malia, "No TitlePemerintah Tertibkan 9 Rumpon Ilegal, Banyak Ditemui yang Tak Berizin," 12 April 2018. [Online]. Available: https://www.idntimes.com/news/indonesia/indianamalia/pemerintah-tertibkan-9rumpon-ilegal-banyak-ditemui-yang-tak-berizin-1/3. [Accessed: 14-Jan-2019].

[29] N. N. Nugroho, H., Sufyan, A., and Wiadnyana, "No TitleAplikasi Teknologi Elektronik Log Book Penangkapan Ikan untuk Mendukung Pengelolaan Perikanan," J. Kelaut. Nas., vol. 10, no. 3, pp. 113-124, 2017.

[30] D. B. Suharto, B. Y., Budiman, J., \& Karwur, “Analisis Pengawasan Kapal Perikanan 
terhadap Penanggulangan Illegal Fishing di Perairan Kabupaten Kepulauan Sangihe, Indonesia," J. Kebijak. Sos. Ekon. Kelaut. dan Perikan., vol. 7, no. 2, pp. 115-125, 2018. 